
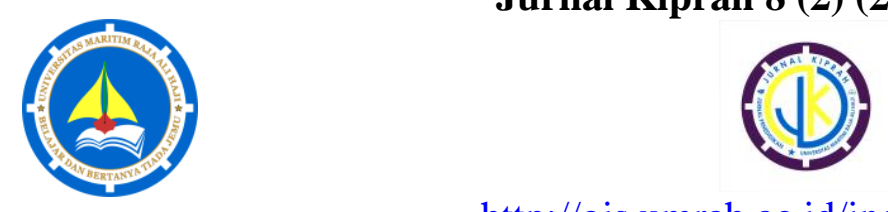

http://ojs.umrah.ac.id/index.php/kiprah

p-ISSN 2354-7278 | e-ISSN 2580-6947

\title{
Analisis Miskonsepsi Siswa pada Materi Bangun Datar dan Bangun Ruang
}

\author{
Urip Nurul Fajari* \\ SDN 1 Sirandu, Purbalingga, Indonesia \\ Pengiriman: 26/02/2020; Diterima: 19/10/2020; Publikasi: 20/11/2020
}

DOI: 10.31629/kiprah.v8i2.2071

\begin{abstract}
Abstrak
Matematika merupakan bidang studi yang memegang peranan penting dalam pendidikan. Geometri adalah salah satu materi dari matematika yang diajarkan di sekolah dasar. Geometri sering dianggap sebagai materi yang paling sulit dipahami karena memiliki istilah-istilah yang tidak mudah untuk dipahami. Permasalahan geometri yang paling sering muncul di sekolah dasar adalah miskonsepsi. Penelitian ini bertujuan untuk menganalisis miskonsepsi siswa pada materi bangun datar dan bangun ruang, penyebab, dan solusi penanganannya. Penelitian ini menggunakan metode kualitatif dengan pendekatan deskriptif eksploratif. Subjek penelitian ini adalah 56 siswa siswa kelas 5 SDN 2 Karangreja dan Sekolah Dasar (SD) Negeri 1 Sirandu. Hasil penelitian menunjukkan bahwa siswa mengalami miskonsepsi pada materi: (1) posisi posisi segiempat, istilah segiempat, dan hubungan antar bentuk-bentuk segiempat; (2) istilah luas daerah bangun datar; (3) alas prisma; (4) garis tinggi limas; (5) sisi balok; dan (6) rusuk kerucut. Miskonsepsi siswa disebabkan oleh beberapa faktor, yaitu (1) penjelasan guru yang tidak menyeluruh; (2) siswa belum memahami istilah-istilah dasar seperti sisi, rusuk, dll.; (3) siswa terbiasa dengan posisi bangun datar atau bangun ruang yang horizontal; (4) pembelajaran tanpa visualisasi benda konkret. Adapun solusi penanganannya adalah dengan menggunakan media pembelajaran yang konkret dan menarik serta menjelaskan perbedaan istilah-istilah bangun datar maupun bangun ruang secara menyeluruh.
\end{abstract}

Kata kunci: bangun datar; bangun ruang; matematika; miskonsepsi; sekolah dasar

\begin{abstract}
Mathematics is a field of study that plays an important role in education. Geometry is one of the materials from mathematics taught in elementary schools. Geometry is often considered the most difficult material to understand because it has terms that are not easy to understand. The most common geometry problem that arises in elementary schools is misconception. This study aims to analyze students' misconceptions on twodimensional figure material and geometry, their causes, and their handling solutions. The research method used is qualitative with a descriptive exploratory approach. The subjects of this study were 56 fifth grade students of SDN 2 Karangreja and SDN 1 Sirandu. The results showed that there were students' misconceptions on the material: (1) quadrilateral positions, quadrilateral terms, and relationships between quadrilateral forms; (2) the term area of a two-dimensional figure; (3) the base of the prism; (4) pyramid altitude; (5) cuboid side; and (6) cone edge. Student misconceptions are caused by several factors, namely (1) incomplete teacher explanation; (2) students have not yet understood basic terms such as sides, edges, etc.; (3) students are accustomed to horizontal two-dimensional figure or geometry positions; (4) learning without visualization of concrete objects. The solution is to use concrete and interesting learning media, and explain the differences in terms of twodimensional figures and geometry as a whole.
\end{abstract}

Keywords: geometry; mathematics; misconception; primary school; two-dimensional figure 


\section{PENDAHULUAN}

Matematika merupakan bidang studi yang memegang peranan penting sebagai dasar, rujukan, atau pedoman dari ilmu pengetahuan lain. Salah satu pelajaran yang banyak menimbulkan miskonsepsi pada siswa sekolah dasar adalah geometri. Geometri adalah penguraian tentang objek-objek dimensi baik satu, dua, maupun tiga dimensi untuk membekali siswa dengan kemampuan visual objek. Geometri merupakan bagian matematika yang sulit dipahami siswa, dan juga sulit diajarkan oleh guru (Sutiarso \& Coesamin, 2013). Hal ini juga sejalan dengan hasil wawancara Guru kelas V yang menyatakan, "Materi yang paling banyak membuat siswa bingung adalah geometri. Siswa mengaku sudah memahaminya, tetapi saat diminta mengerjakan soal, mereka banyak salahnya". Fakta tersebut juga didukung oleh hasil ulangan harian siswa pada materi geometri, dari 56 siswa, hanya 27 siswa atau sekitar $48,21 \%$ yang mempunyai nilai di atas KKM sekolah.

Geometri dianggap materi yang sulit dipahami karena karakteristik geometri yang membutuhkan kemampuan visual atau imajinasi dan kemampuan menganalisis yang tinggi untuk memahami objek yang tidak nyata, sedangkan siswa sekolah dasar berada pada tahap operasional konkret yang harus menggunakan benda-benda konkret untuk memahami sesuatu. Hal inilah yang menyebabkan geometri memiliki peluang besar menimbulkan miskonsepsi matematika pada siswa sekolah dasar.

Sholihat et al. (2017) menyatakan, "Miskonsepsi merupakan ketidaksesuaian pemahaman yang sering dialami siswa yang menimbulkan hambatan penguasaan materi". Lebih lanjut lagi, Ross et al. (2006) dan A'yun, Q., Harjito, \& Nuswowati (2018) mendefinisikan miskonsepsi sebagai pemahaman konsep yang tidak sesuai dengan penjelasan ilmiah sehingga menyebabkan kesulitan belajar seorang siswa. Hal ini sejalan dengan pendapat Putra et al. (2016) yang mengemukakan bahwa miskonsepsi merupakan konsep awal yang dimiliki siswa dan terus-menerus dipegang sebagai pedoman, tetapi tidak sesuai dengan konsep ilmiah.

Faktor-faktor yang menyebabkan terjadinya miskonsepsi yaitu: siswa, guru, buku teks, konteks, dan metode mengajar (Tayubi, 2005). Miskonsepsi memiliki sifat yang tahan terhadap perubahan, sehingga sulit sekali untuk diubah. Miskonsepsi pada siswa juga dapat disebabkan oleh prakonsepsi yang salah dari pemahaman sebelumnya yang mereka miliki, mulai dari kurang lengkapnya informasi atau bahkan salah informasi (Sheftyawan et al., 2018). Namun, miskonsepsi ini sering disalahartikan dengan kesalahan siswa yang disebabkan oleh kemampuan spasial siswa yang belum memadai. Kemampuan spasial itu sendiri merupakan kemampuan individu untuk melihat dan membayangkan benda-benda ruang dengan hanya membuat gambar-gambar benda ruang tersebut di atas kertas (Anjarsari, 2019). Sering kali miskonsepsi dianggap sama dengan rendahnya kemampuan spasial siswa.

Fakta di lapangan menunjukkan adanya miskonsepsi siswa pada materi geometri. Miskonsepsi ditemukan pada siswa jenjang sekolah dasar hingga jenjang sekolah menengah atas (Adriani et al., 2019; Gradini, 2016; Subanji, T, K., Sulandra, 2016). Bahkan penelitian Dzulfikar \& Vitantri (2017) menunjukkan bahwa terdapat miskonsepsi matematika pada guru sekolah dasar terutama materi geometri. Lebih lanjut lagi, penelitian yang dilakukan oleh Mutia (2017) dengan judul "Analisis Kesulitan Siswa SMP dalam Memahami Konsep Kubus Balok dan Alternatif Pemecahannya" menunjukkan bahwa bahwa siswa masih kesulitan memahami konsep kubus dan balok yang dikarenakan kebiasaan siswa menghafal bukan memahami konsep. Penelitian ini dengan penelitian tersebut mempunyai persamaan yaitu mengangkat tema miskonsepsi pada materi geometri. Adapun perbedaannya terletak pada subjek penelitian dan cakupan materi penelitian. Subjek penelitian ini adalah siswa kelas V sekolah dasar, sedangkan subjek 
penelitian tersebut adalah siswa sekolah menengah pertama. Selain itu, cakupan materi penelitian ini lebih luas yaitu bangun datar dan bangun ruang, sedangkan penelitian tersebut hanya menggunakan materi balok dan kubus saja.

Miskonsepsi jika tidak segera ditangani sejak dini dengan cara yang tepat akan menimbulkan berbagai masalah di pembelajaran selanjutnya atau bahkan menimbulkan miskonsepsi yang berkelanjutan (Adriani et al., 2019). Selain itu, miskonsepsi juga harus dikaji terutama oleh guru karena pemahaman guru mengenai miskonsepsi merupakan salah satu bentuk dari pedagogical content knowledge (Schoenfeld, 2015). Pembelajaran matematika di sekolah dasar memerlukan pemahaman konsep yang tinggi. Siswa yang sudah mengalami miskonsepsi pada materi dasar akan memegang konsep yang salah ke jenjang ke depannya. Oleh karena itu, perlu adanya pengkajian miskonsepsi di jenjang sekolah dasar.

Berdasarkan pendahuluan di atas, penelitian ini bertujuan untuk menganalisis miskonsepsi siswa pada materi bangun datar dan bangun ruang, penyebab, dan solusi penanganannya. Adapun rumusan masalah penelitian ini adalah: (1) "bagaimana miskonsepsi siswa pada materi bangun datar, penyebab, dan solusi penanganannya?"; dan (2) "bagaimana miskonsepsi siswa pada materi bangun ruang, penyebab, dan solusi penanganannya?".

\section{METODE PENELITIAN}

Metode penelitian yang digunakan dalam metode penelitian kualitatif dengan pendekatan deskriptif eksploratif. (Mudjiyanto, 2018) menyatakan, "Penelitian tipe deskriptif eksploratif merupakan penelitian yang bertujuan untuk memperdalam pengetahuan dan mencari ide-ide baru mengenai suatu gejala atau fenomena tertentu dan menjelaskan bagaimana terjadinya fenomena tersebut secara lebih terperinci”.

Penelitian ini dilaksanakan di SD

Negeri 2 Karangreja dan SD Negeri 1 Sirandu.
Subjek penelitian ini adalah 23 siswa kelas V SD Negeri 2 Karangreja dan 23 siswa kelas V SD Negeri 1 Sirandu, serta guru kelas V di sekolah masing-masing. Selain itu, beberapa siswa dipilih sebagai informan dengan pertimbangan: (1) ketersediaan siswa; (2) mudah diajak berkomunikasi; serta (3) jawaban siswa mengindikasikan adanya miskonsepsi.

Teknik pengumpulan data penelitian ini terbagi menjadi teknik tes dan non tes. Teknik tes dilakukan dengan memberi soal mengenai bangun datar dan bangun ruang yang sudah dikonsultasikan terlebih dahulu dengan guru kelas. Adapun teknik non tes dilakukan dengan mewawancarai siswa dan guru untuk mendapatkan tambahan data. Instrumen yang digunakan pada penelitian ini adalah instrumen tes tertulis bangun datar dan bangun ruang, serta pedoman wawancara.

Teknik uji keabsahan data menggunakan teknik triangulasi yang terdiri dari triangulasi teknik dan sumber data. Triangulasi teknik yang dimaksud adalah dengan menggunakan teknik pengambilan data lebih dari satu agar data lebih absah. Selanjutnya, triangulasi sumber data yang dimaksud adalah penelitian ini menggunakan tiga sumber data yaitu dokumen, siswa, dan guru kelas.

Analisis data pada penelitian ini dilakukan dengan mengacu pada model analisis data Miles dan Huberman, yaitu reduksi data, penyajian data, dan penarikan simpulan (Sugiyono, 2016). Reduksi data merupakan proses pemilihan, pengkategorian atau pengelompokkan data sesuai dengan tema penelitian. Penyajian data adalah representasi data penelitian dalam bentuk tabel, grafik, diagram, bagan, dll. Sementara itu, penarikan simpulan adalah proses verifikasi data secara bertahap hingga mendapatkan simpulan penelitian final.

\section{HASIL DAN PEMBAHASAN}

Data miskonsepsi pada penelitian ini diperoleh dari hasil tes 56 siswa materi bangun datar dan bangun ruang. Soal tes terdiri dari 
tiga puluh soal uraian yang penuh dengan gambar bangun datar dan bangun ruang.

\section{Miskonsepsi Bangun Datar}

Terdapat beberapa miskonsepsi siswa pada materi bangun datar, yaitu (1) miskonsepsi posisi segiempat, istilah segiempat serta hubungan antar bangun datar segiempat dan (2) istilah luas daerah bangun datar. Miskonsepsi yang pertama adalah miskonsepsi siswa pada posisi segiempat. Siswa menganggap bahwa segiempat yang posisinya tidak mendatar bukan merupakan segiempat.

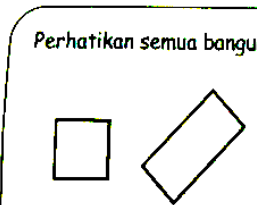

(1)

(2)

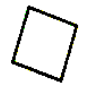

(3)

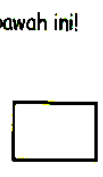

(4)

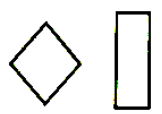

(5) (6)
Pada gambar di atas, tulislah bangun datar bernomor yang mana saja yang termasuk kelompok atau jenis persegipanjang?

Jawab: . 4 ...

Gambar 1. Miskonsepsi Posisi Persegi Panjang

Gambar 1 menunjukkan adanya miskonsepsi siswa terhadap posisi persegi panjang, Sebanyak enam siswa menjawab bangun datar 4, yang berarti mereka menganggap persegi panjang hanya jika dalam posisi horizontal yaitu dengan sisi mendatar (dalam arah pandang pembaca) adalah sisi terpanjang, sedangkan persegi panjang dengan posisi tidak mendatar bukan merupakan persegi panjang.

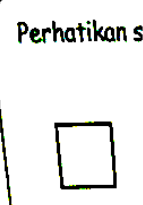

(1)

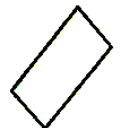

(2)

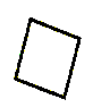

(3)

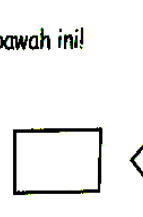

(4)

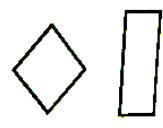

(5) (6)
Pada gambar di atos, tulislah bangun datar bernomor yang mana saja yang termasuk kelompok atau jenis perseg?

Jawab: .

Gambar 2. Miskonsepsi Posisi Persegi

Gambar 2 menunjukkan bahwa siswa tidak hanya miskonsepsi akan posisi persegi panjang saja melainkan juga pada posisi persegi. Tiga belas siswa menjawab bangun datar 1 yang berarti mereka menganggap persegi hanya sebagai bangun datar yang berbentuk persegi dan mendatar, sedangkan persegi dengan posisi tidak mendatar dianggap bukan persegi. Miskonsepsi siswa juga terjadi pada bentuk jajargenjang, trapesium, persegi panjang, persegi, dan layang-layang.

Miskonsepsi siswa tersebut disebabkan oleh kebiasaan guru saat menjelaskan persegi panjang yang selalu dalam posisi horizontal. Guru selalu menggambar bentuk persegi panjang dengan memvisualisasikan posisi sisi terpanjang mendatar terhadap arah pembaca, sehingga saat siswa dihadapkan dengan persegi panjang yang posisinya tidak horizontal, maka mereka tidak bisa mengidentifikasinya. Hal ini sejalan dengan pendapat Dedy \& Sumiaty (2017) yang mengemukakan bahwa siswa menjadi miskin konteks karena selalu meniru contoh yang sudah ada dan tidak memahami konstruksi konsep dari hasil pemikirannya sendiri.

Adapun alternatif solusi penanganan permasalahan segi empat yaitu guru menjelaskan bentuk-bentuk segiempat dengan berbagai posisi sehingga siswa tidak miskonsepsi dengan posisi segi empat. Kemudian, guru sebaiknya menanamkan pemahaman dengan menyajikan gambar persegi panjang atau menggunakan alat peraga dengan berbagai posisi. Hal ini didukung oleh pendapat Gita et al. (2018) yang menyatakan miskonsepsi yang terjadi dapat disebabkan oleh cara mengajar dan penyajian gambar.

Miskonsepsi siswa selanjutnya adalah siswa mengalami miskonsepsi mengenai istilah segiempat. Terdapat dua siswa yang menganggap layang-layang dan trapesium dianggap bukan segiempat. 
Perhatikan gambar berikut:

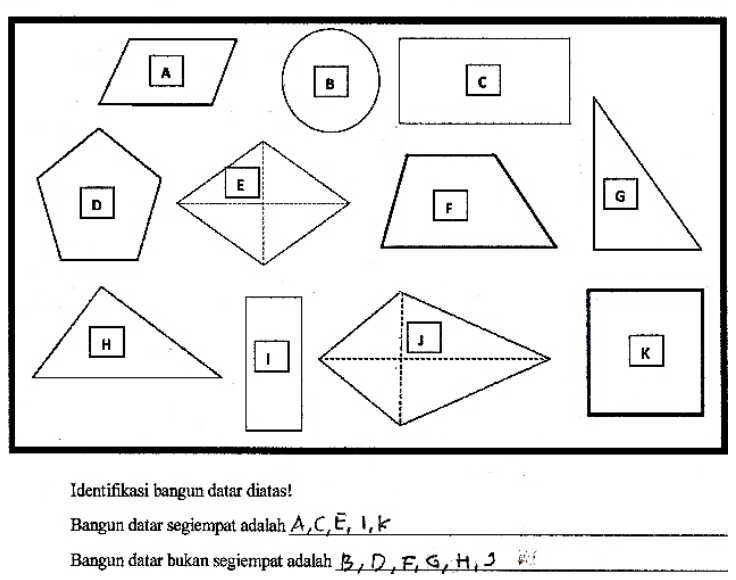

Gambar 3. Miskonsepsi Istilah Segiempat

Gambar 3 menunjukkan adanya miskonsepsi siswa pada istilah segiempat karena siswa menganggap layang-layang dan trapesium bukan merupakan bangun datar segiempat. Hasil wawancara dengan Guru kelas V menunjukkan bahwa guru telah menjelaskan kepada siswa dengan jelas dengan menanamkan pemahaman bahwa segiempat adalah bangun yang "pucuknya" atau sudutnya berjumlah empat. Selain itu, pada soal yang menguji miskonsepsi siswa terhadap hubungan antar bangun datar, siswa menganggap persegi bukan merupakan jenis persegi panjang. Hal ini nampak pada jawaban siswa di Gambar 4 berikut.

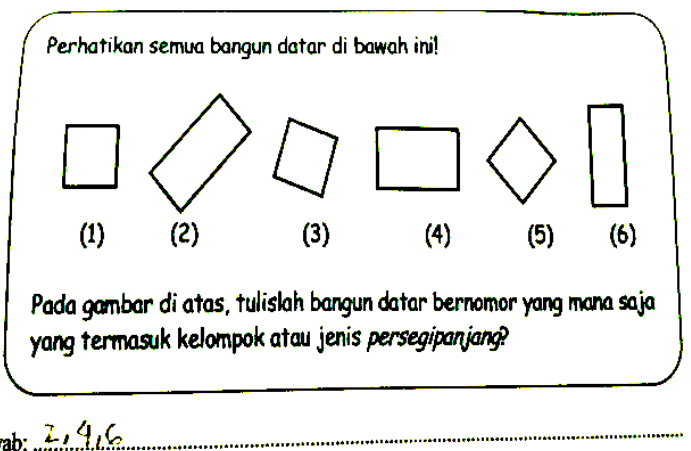

Gambar 4. Miskonsepsi Hubungan antar Bangun Datar Segiempat

Gambar 4 menunjukkan adanya miskonsepsi. Hal ini dikarenakan seluruh siswa menjawab persegi panjang sebagai bangun datar yang ditunjukkan oleh nomor 2, 4, dan 6, sedangkan bangun datar 1, 3, dan 5 bukan persegi panjang. Padahal persegi termasuk jenis persegi panjang, karena pengertian dari persegi adalah persegi panjang yang semua sisinya sama panjang. Penelitian Dzulfikar \& Vitantri (2017) juga menyimpulkan bahwa terdapat 24 responden guru sekolah dasar yang mengalami miskonsepsi akan hal yang sama. Hal ini mengindikasikan bahwa siswa mengalami miskonsepsi dan tidak memahami hubungan antar bangun datar segiempat.

Miskonsepsi siswa mengenai hubungan antar bangun datar ini disebabkan oleh minimnya penjelasan keterkaitan bangun datar secara menyeluruh. Selama ini guru menjelaskan bangun datar satu per satu, atau dengan kata lain guru langsung mengerucut ke pengertian masing-masing bangun datar sehingga siswa tidak menyadari keterkaitan tersebut. Hal ini didukung oleh pendapat Kiswanto et al. (2015) yang menyatakan, "Persepsi dan fokus perhatian siswa mengacu pada informasi yang diperolehnya". Guru terlalu fokus mempelajari bentuk-bentuk khusus segiempat tanpa menyinggung hubungan antar segiempat secara umum. Padahal konsepsi siswa dominan bergantung pada keluasaan informasi yang dihadirkan guru (Kusaeri, 2017).

Adapun solusi penanganan miskonsepsi hubungan antar bangun datar adalah dengan menjelaskan secara menyeluruh keterkaitan antar bangun datar dengan bagan atau mind mapping, sehingga siswa memahami keterkaitannya. Hal ini didukung oleh pendapat Irfan (2017) dan Liu et al. (2014) yang menyatakan bahwa kelebihan mind mapping yaitu memberi pandangan atau gambaran materi secara menyeluruh, membantu memahami, mengatur, mengingat, membandingkan, dan membuat hubungan atau keterkaitan, memfokuskan pembelajaran pada inti materi serta lebih menarik bagi siswa. Bagan penjelasan yang bisa digunakan sebagai referensi dalam menjelaskan keterkaitan bangun datar dapat dilihat pada gambar 5 berikut. 


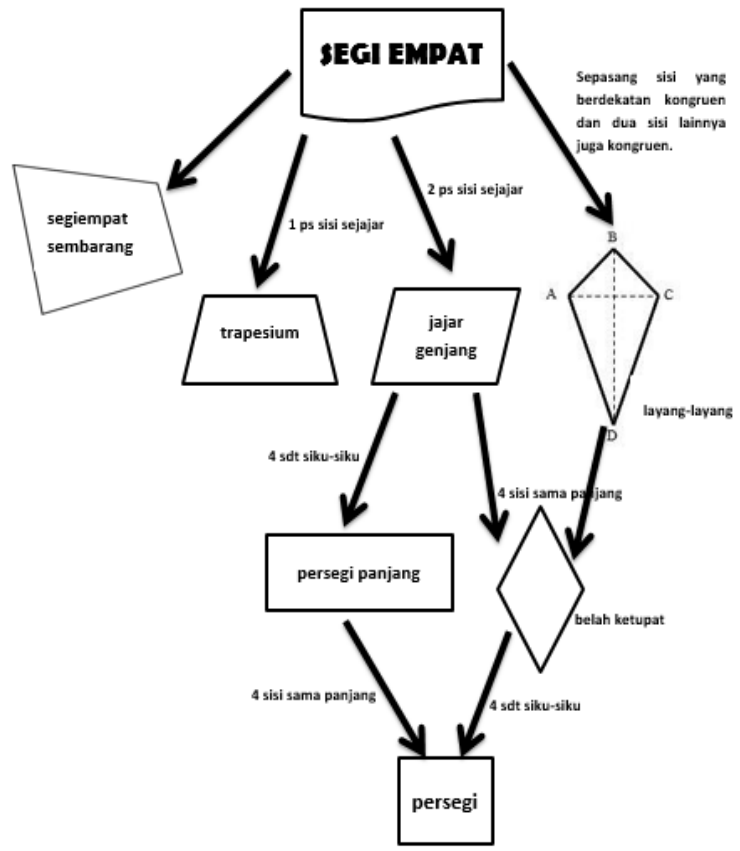

Gambar 5. Bagan Hubungan Antar Segiempat

Miskonsepsi bangun datar selanjutnya adalah siswa miskonsepsi mengenai istilah luas daerah bangun datar dan luas bangun datar. Padahal luas daerah bangun datar dan luas bangun datar memiliki definisi yang berbeda. Miskonsepsi siswa ini nampak saat pembelajaran. Guru dan siswa selalu menyebut luas bangun datar tanpa mengetahui perbedaan istilah luas daerah bangun datar dan luas bangun datar.

Solusi yang dapat diterapkan yaitu dengan menjelaskan perbedaan luas daerah bangun datar dan luas bangun datar dengan tegas, serta membiasakan penggunaan istilah luas daerah bangun datar. Sebagai contoh, guru seharusnya menjelaskan lingkaran sebagai tempat kedudukan titik-titik yang jaraknya sama ke suatu titik tertentu. Berdasarkan pemahaman pengertian tersebut, maka siswa seharusnya memahami berapapun jari-jarinya maka luas lingkaran seharusnya 0 , sedangkan rumus luas lingkaran yang selama ini diajarkan merupakan rumus untuk mengitung luas daerah yang dibatasi oleh titiktitik yang disebut lingkaran tersebut. Hal ini didukung oleh pendapat Chick \& Baker (2005) yang menyatakan bahwa guru harus menanamkan pemahaman dan penguasaan konsep yang baik serta mengetahui letak miskonsepsi siswa agar terhindar dari miskonsepsi.

\section{Miskonsepsi Bangun Ruang}

Terdapat beberapa miskonsepsi pada materi bangun ruang yaitu miskonsepsi istilah (1) alas prisma segitiga; (2) garis tinggi limas segiempat; (3) rusuk kerucut; dan (4) sisi balok. Miskonsepsi siswa pada materi bangun ruang yang pertama adalah miskonsepsi dalam penentuan alas bangun ruang. Sama seperti miskonsepsi pada bangun datar, siswa tidak bisa mengidentifikasi alas bangun ruang saat bangun yang disuguhkan tidak dalam posisi horizontal atau mendatar. Pada miskonsepsi bangun ruang, siswa tidak bisa mengidentifikasi bagian-bagian bangun ruang saat bangun ruang tersebut tidak berada dalam posisi vertical. Hal ini ditunjukkan dengan menganalisis jawaban siswa pada Gambar 6 berikut.

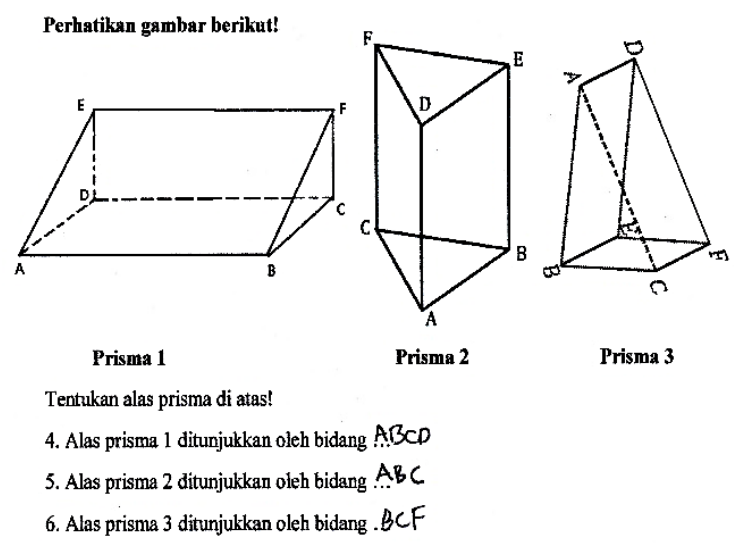

Gambar 6. Miskonsepsi Alas Prisma

Gambar 6 menunjukkan adanya miskonsepsi karena 22 siswa menganggap alas prisma segitiga selalu berada di sisi paling bawah pada berdiri atau vertikal, apapun jenis bangun ruangnya. Miskonsepsi siswa terhadap alas prisma ini disebabkan oleh pemahaman siswa akan prisma itu sendiri. Siswa lebih memahami prisma sebagai bangun ruang yang memiliki alas dan atas dibandingkan dengan bangun ruang yang dibatasi oleh 2 bidang yang bentuk dan ukurannya sama dan sejajar. Hal ini yang menyebabkan siswa kesulitan mengidentifikasi alas dan atas saat prisma tidak dalam posisi berdiri atau vertikal. 
Beberapa penelitian juga menyatakan siswa mengalami kesulitan dalam menentukan alas prisma saat prisma tidak dalam posisi vertikal (Ainiyah \& Sugiyono, 2016; Nurjanatin et al., 2017; Rosilawati \& Alghadari, 2018). Lebih lanjut lagi, siswa mengalami miskonsepsi dalam menentukan garis tinggi limas segiempat. Hal ini nampak pada jawaban siswa yang tertera di Gambar 7 .

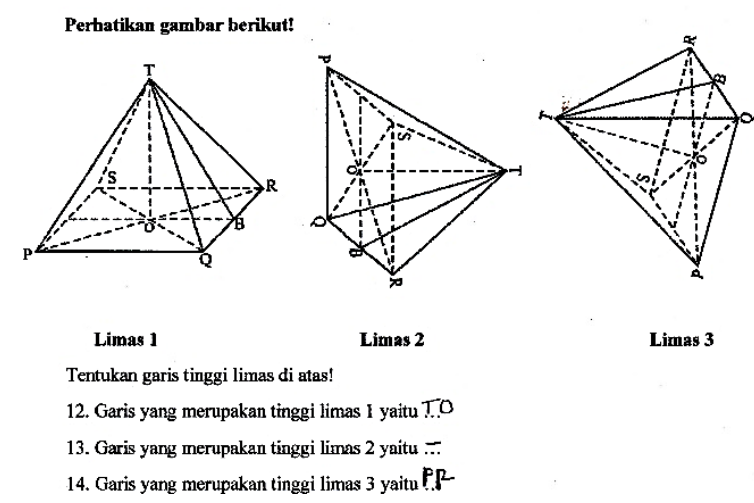

Gambar 7. Miskonsepsi Tinggi Limas

Gambar 7 menunjukkan bahwa siswa mengalami miskonsepsi pada saat menentukan garis tinggi limas segiempat. 13 siswa menyatakan bahwa limas yang ditidurkan tidak memiliki garis tinggi. Selain itu, 23 siswa juga menjawab garis PR merupakan tinggi limas 3. Hal ini didukung oleh hasil wawancara dengan siswa yang menyatakan bahwa siswa menganggap bahwa garis tinggi limas posisinya selalu vertikal.

Miskonsepsi siswa terhadap tinggi limas ini disebabkan oleh kebiasaan guru dalam menvisualisasikan garis tinggi limas yang selalu dalam posisi vertikal sehingga siswa tidak bisa mengidentifikasi garis tinggi limas saat limas dimiringkan atau horizontal. Persepsi visual siswa berperan penting dalam menentukan keberhasilan siswa untuk mengidentifikasi bagian-bagian bangun datar. Adanya persepsi yang tidak sesuai konsep dikarenakan minimnya pemahaman yang hanya berdasar pada pengalaman perseptual saja (Bueno, 2013). Hal ini sejalan dengan penelitian Rosilawati \& Alghadari (2018) yang mengungkapkan bahwa perspektif setiap siswa dengan kemampuan pengamatan dan konsep geometri yang berbeda akan memberikan hasil yang berbeda pula. Ainiyah \& Sugiyono (2016) dalam penelitiannya juga menyatakan, "Siswa dapat mengalami miskonsepsi klasifikasional yang meliputi kesalahan dalam menentukan unsur-unsur yang terdapat pada bangun ruang, salah satunya limas".

Kemudian, siswa mengalami miskonsepsi mengenai garis pelukis dan rusuk kerucut. Siswa miskonsepsi dengan menganggap garis pelukis pada kerucut sebagai rusuknya. Hal ini ditunjukkan oleh jawaban siswa pada Gambar 8 berikut.

\section{Perhatikan gambar berikut!}

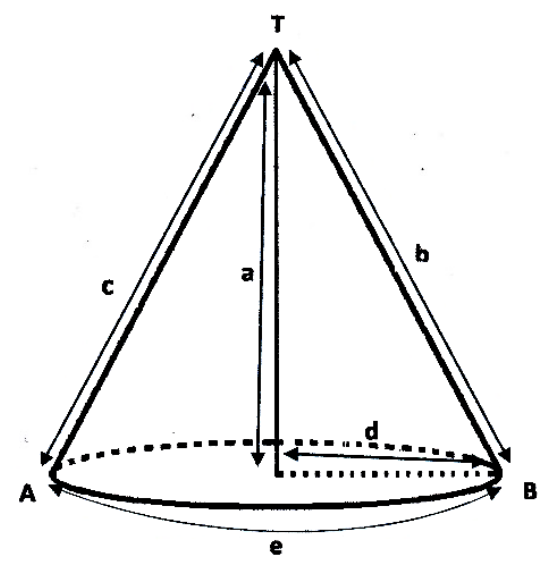

Identifikasi bagian-bagian kerucut di atas!

$$
\text { 16. Bagian a adalah tinggi }
$$

18. Bagian c adalah rusuk

19. Bagian d adalah jạrījari

20. Bagian e adalah alas

Gambar 8. Miskonsepsi Rusuk Kerucut

Gambar 8 menunjukkan siswa tidak bisa membedakan garis pelukis dengan rusuk kerucut. Sebanyak 38 siswa mengira garis TA dan TB merupakan rusuk kerucut, sehingga kerucut merupakan bangun ruang dengan 3 rusuk. Hal ini disebabkan oleh penjelasan guru mengenai unsur-unsur kerucut yang dominan menggunakan gambar atau dua dimensi saja. Siswa melihat kerucut yang divisualisasikan dengan media dua dimensi sebagai garis yang sama-sama terlihat seperti garis pada prisma, limas, balok, dan kubus. Oleh karena itu, miskonsepsi siswa terjdai dengan menganggap garis TA dan TB sebagai rusuk. 
Fakta adanya miskonsepsi siswa pada materi kerucut ini didukung oleh penelitian Mutia (2017) yang menyatakan bahwa siswa kesulitan mengidentifikasi bagian-bagian kerucut. Miskonsepsi tersebut bisa disebabkan oleh rendahnya kecerdasan visual-spasial siswa (Gradini, 2016). Miskonsepsi bangun ruang selanjutnya adalah miskonsepsi siswa pada penentuan sisi bangun ruang balok. Siswa sering mengira jika sisi bangun ruang adalah rusuk, begitupun sebaliknya, rusuk adalah sisi. Hal ini nampak pada jawaban siswa yang tertera di Gambar 9 .

\section{Perhatikan gambar berikut!}

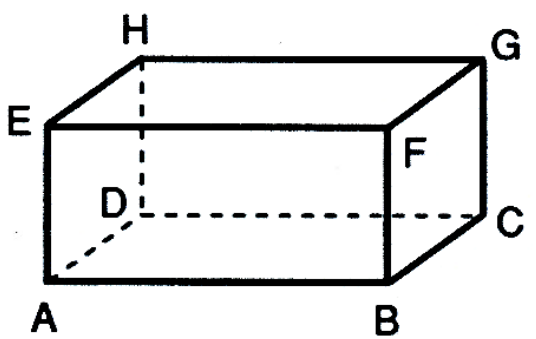

Identifikasi bagian-bagian balok di atas!

21. Jumlah titik sudut $=.8$

22. Nama-nama titik sudut $=A, B, C, D, E, F, G,+1$

23. Jumlah rusuk $=$ L?

24. Nama-nama rusuk $=B C G F, A D H E$,

25. Jumlah bidang sisi $=6$.

26. Nama-nama bidang sisi $=A B$ dan $C D, E F$ dan $G H$,

Gambar 9. Miskonsepsi Sisi Balok

Gambar 9 menunjukkan miskonsepsi siswa terhadap sisi dan rusuk bangun ruang. Terdapat sebelas siswa yang mengalami miskonsepsi akan hal tersebut. Berdasarkan hasil wawancara dengan beberapa siswa, siswa dapat menyebutkan jumlah dari sisi dan rusuk pada balok dengan benar, tetapi saat diminta untuk menunjukkan letak rusuk dan sisi tersebut mereka masih kebingungan. Hal ini dikarenakan siswa menggunakan ingatannya dalam menghafalkan bagian-bagian balok dan bentuk bangun ruang lain. Miskonsepsi siswa ini disebabkan karena cara siswa dalam memahami materi yaitu dengan menghafal tanpa memperhatikan konsepnya (Kiswanto et al., 2015).
Penyebab timbulnya miskonsepsi klasifikasional adalah siswa tidak bisa membayangkan gambar pada soal dengan baik (Sopiany \& Rahayu, 2019). Maka dari itu, pembelajaran sisi dan rusuk bangun ruang akan mudah dipahami saat siswa dapat memegang bentuk dari bangun ruang itu sendiri. Padahal selama ini, siswa disuguhkan dengan gambar-gambar yang berbentuk garisgaris saja sehingga konsep bangun ruang mempunyai potensi yang besar untuk menimbulkan miskonsepsi siswa. Beberapa penelitian juga menyimpulkan hal yang sama yaitu adanya miskonsepsi pada bagian-bagian balok dan kubus (Ainiyah \& Sugiyono, 2016; Mutia, 2017; Rosilawati \& Alghadari, 2018).

\section{KESIMPULAN}

Berdasarkan analisis hasil penelitian dan pembahasan, maka dapat diperoleh informasi bahwa siswa mengalami miskonsepsi pada materi: (1) posisi posisi segiempat, istilah segiempat, dan hubungan antar bentuk-bentuk segiempat; (2) istilah luas daerah bangun datar; (3) alas prisma; (4) garis tinggi limas; (5) sisi balok; dan (6) rusuk kerucut. Miskonsepsi siswa disebabkan oleh beberapa faktor, yaitu (1) penjelasan guru yang tidak menyeluruh; (2) siswa belum memahami istilah-istilah dasar seperti sisi, rusuk, dll.; (3) siswa terbiasa dengan posisi bangun datar atau bangun ruang yang horizontal; dan (4) pembelajaran tanpa visualisasi benda konkret. Adapun solusi untuk menangani miskonsepsi siswa tersebut adalah dengan menggunakan media pembelajaran yang konkret dan menarik, dan menjelaskan perbedaan istilah-istilah bangun datar maupun bangun ruang secara menyeluruh.

Penelitian ini hanya berdasarkan hasil analisis miskonsepsi di dua sekolah dasar saja, sehingga fakta yang dijabarkan belum tentu dapat mewakili sekolah dasar lain. Selain itu, mungkin masih ada miskonsepsi yang belum sepenuhnya terungkap. Oleh karena itu, penelitian selanjutnya seharusnya dapat memperluas subjek penelitian serta mengambil cakupan materi yang lebih dalam dan beragam, sebagai contoh satu mata pelajaran dengan berbagai kompetensi dasar, atau tematema yang ada di kurikulum 2013. 


\section{REFERENSI}

A’yun, Q., Harjito, \& Nuswowati, M. (2018). Analisis Miskonsepsi Siswa Menggunakan Tes Diagnostic Multiple Choice Berbantuan CRI (Certainty Of Response Index). Jurnal Inovasi Pendidikan Kimia, 12(1), 2108-2117.

Adriani, W., Selaras, G. H., \& Yogica, R. (2019). The Identification of Levels of Concept Understanding Using Three-Tier Multiple Choice Diagnostic Test Identifikasi Tingkat Pemahaman Konsep Menggunakan Three-Tier Multiple Choice Diagnostic Test. Atrium Pendidikan Biologi, 4(2), 11-19.

Ainiyah, L. A., \& Sugiyono. (2016). Identifikasi Miskonsepsi Siswa Dalam Materi Geometri Pada Pembelajaran Matematika Siswa Kelas Viii Smp Negeri 1 Punggelan. Jurnal Pendidikan Matematika-S1, 5(11), 1-10.

Anjarsari, E. (2019). Mengembangkan Kemampuan Spasial Siswa Melalui Pendekatan Saintifik dalam Pembelajaran Matematika. Jurnal Reforma, 7(2), 5561. https://doi.org/10.30736/rfma.v7i2.77

Bueno, O. (2013). Perception and Conception: Shaping Human Minds. Biosemiotics, 6(3), 323-336. https://doi.org/10.1007/s12304-0139170-z

Chick, H. L., \& Baker, M. (2005). Investigating Teachers'Responses To Student Misconceptions. Psychology of Mathematics Education, 2, 249-256.

Dedy, E., \& Sumiaty, E. (2017). Desain Didaktis Bahan Ajar Matematika SMP Berbasis Learning Obstacle dan Learning Trajectory. Jurnal Review Pembelajaran Matematika, 2(1), 69-80. https://doi.org/10.15642/jrpm.2017.2.1.6 9-80

Dzulfikar, A., \& Vitantri, C. A. (2017). Miskonsepsi Matematika pada Guru Sekolah Dasar. Suska Journal of Mathematics Education, 3(1), 41-48. https://doi.org/10.24014/sjme.v3i1.3409

Gita, A., Murnaka, N. P., \& Sukmawati, K. I. (2018). Penerapan Model Pembelajaran Conceptual Understanding Procedures (CUPS) sebagai Upaya Mengatasi Miskonsepsi Matematis Siswa. Journal of Medives: Journal of Mathematics Education IKIP Veteran Semarang, 2(1), 65-76. https://doi.org/10.31331/medives.v2i1.52 1

Gradini, E. (2016). Miskonsepsi Dalam Pembelajaran Matematika Sekolah Dasar di Dataran Tinggi Gayo. Journal of Chemical Information and Modeling, $3(2), 52-60$.

Irfan, M. (2017). Pengembangan Lembar Kerja Siswa Berbasis Metode Mind Map Pada Mata Pelajaran IPA Di Sekolah Dasar. JIKAP PGSD: Jurnal Ilmiah Ilmu Kependidikan, 1(2), 107-114. https://doi.org/10.26858/jkp.v1i2.5278

Kiswanto, Rahman, U., \& Sulasteri, S. (2015). Deskripsi Pemahaman Konsep Materi Geometri ditinjau dari Kepribadian Sensing dan Intuition pada Siswa Kelas IX SMP N 33 Makassar. MaPan: Jurnal Matematika Dan Pembelajaran, 3(1), 42-58.

Kusaeri, K. (2017). Terbentuknya Konsepsi Matematika Pada Diri Anak dari Perspektif Teori Reifikasi dan Apos. JPM: Jurnal Pendidikan Matematika, 1(2), 101-105. https://doi.org/10.33474/jpm.v1i2.244

Liu, Y., Zhao, G., Ma, G., \& Bo, Y. (2014). The Effect of Mind Mapping on Teaching and Learning: A MetaAnalysis. Standard Journal of Education and Essay, 2(1), 017-031.

Mudjiyanto, B. (2018). Tipe Penelitian Eksploratif Komunikasi Exploratory Research in Communication Study. Jurnal Studi Komunikasi Dan Media, 22(1), 65-74.

Mutia, M. (2017). Analisis Kesulitan Siswa SMP dalam Memahami Konsep Kubus Balok dan Alternatif Pemecahannya. Beta Jurnal Tadris Matematika, 10(1), 83-102. https://doi.org/10.20414/betajtm.v10i1.10 7

Nurjanatin, I., Sugondo, G., \& Manurung, M. M. (2017). Analisis Kesalahan Peserta Didik Dalammenyelesaikan Soal Cerita Padamateri Luas Permukaan Balok Di Kelas Viii - F Semester Ii Smp Negeri 2 Jayapura. Jurnal Ilmiah Matematika Dan Pembelajaranya, 2(1), 22-31.

Putra, I., Adlim, A., \& Halim, A. (2016). Analisis Miskonsepsi dan Upaya Remediasi Pembelajaran Listrik Dinamis dengan Menggunakan Media 
Pembelajaran Lectora Inspire dan PHET Simulation di SMAN Unggul Tunas Bangsa. Jurnal Pendidikan Sains Indonesia, 7(2), 147-153.

Rosilawati, R., \& Alghadari, F. (2018). Konsepsi Siswa pada Suatu Bentuk Bangun Ruang Terkait dengan Rusuk dan Diagonal Sisi. PRISMA, 7(2), 164176. https://doi.org/10.35194/jp.v7i2.459

Ross, P., Tronson, D., \& Ritchie, R. J. (2006). Modelling photosynthesis to increase conceptual understanding. Journal of Biological Education, 40(2), 84-88. https://doi.org/10.1080/00219266.2006.9 656019

Schoenfeld, A. H. (2015). Mathematics Teaching and Learning. In Handbook of Educational Psychology. University of California.

https://doi.org/10.4324/9780203874790.c h21

Sheftyawan, W. B., Prihandono, T., \& Lesmono, A. D. (2018). Identifikasi Miskonsepsi Siswa Menggunakan Fourtier Diagnostic Test pada Materi Optik Geometri. Jurnal Pembelajaran Fisika, 7(2), 147-153.

Sholihat, F. N., Samsudin, A., \& Nugraha, M. G. (2017). Identifikasi Miskonsepsi dan Penyebab Miskonsepsi Siswa Menggunakan Four-Tier Diagnostic Test Pada Sub-Materi Fluida Dinamik: Azas Kontinuitas. Jurnal Penelitian \& Pengembangan Pendidikan Fisika, 3(2), 175-180.

https://doi.org/10.21009/1.03208

Sopiany, H. N., \& Rahayu, W. (2019). Analisis Miskonsepsi Siswa Ditinjau dari Teori Kontruktivisme Pada Materi Segiempat. Jurnal Pendidikan Matematika, 13(2), 185-200. https://doi.org/10.22342/jpm.13.2.6773.1 85-200

Subanji, T, K., Sulandra, S. I. (2016). Miskonsepsi Pada Penyelesaian Soal Aljabar Siswa Kelas VIII Berdasarkan Proses Berpikir Mason. Jurnal Pendidikan - Teori, Penelitian, Dan Pengembangan, 1(10), 1917-1925. https://doi.org/10.17977/jp.v1i10.6942

Sugiyono. (2016). Metode penelitian kuantitatif, kualitatif,dan R\&D. Bandung: Alfabeta.

Sutiarso, S., \& Coesamin, M. (2013). Identifikasi Kesalahan Matematis Siswa
Kelas V Sekolah Dasar Dalam Geometri. Jurnal Pendidikan MIPA Universitas Lampung, 14(1), 33-38.

Tayubi, Y. R. (2005). Identifikasi Miskonsepsi pada Konsep-Konsep Fisika Menggunakan Certainty of Response Index (CRI). Jurnal UPI, 24(3), 4-9. 